\title{
Reformasi Kultural Orde Baru dalam Perspektif Postmodernisme
}

\author{
Arinto Nurcahyono
}

As a discourse of Postmodernism, deconstruction has a great importance to be used as a tool of cultural reform in Indonesia. When The New Era was in power it developed the "logocentrism culture" through the creation of "biner position" in the structure of language, society, political-economy, and of course, culture. These structures were implemented in the feudalism., totalitarianism, and oppresive manner of the New Era. The stigmatization against some groups as a subversives, dissident or anti-Pancasila, had been very popular during Suharto's regime. Hopefully, the deconstruction perspective, as a tool of reform will encourage changes in Indonesia which meet requirements for globalization. Finally, it recommended that the perspective of deconstruction encourage changes for Indonesia toward the new paradigm and structure which, in turn, satisfy, the internal and global needs.

\section{Pendahuluan}

ampai detik-detik terakhir ini gaung reformasi seakan-akan tidak pernah berhenti bergema Mulai dari para tokoh politik yang mengusulkan penghapusan berbagai undang-undang dan berbagai peraturan politik, para wartawan yang menuntut pemulihan hak penerbitan dan kebebasan pers, para seniman yang menuntut dihilangkannya pembatasan izin pertunjukkan, sampai ibu rumah tangga yang menuntut penurunan harga kebutuhan pokok.

Dari berbagai suara reformasi total tersebut, tuntutan yang pada umumnya dikemukakan adalah membongkar struktur-struktur ekonomi, politik, hukum dan budaya warisan rezim Orde Baru yang telah keropos dan terlalu feodalistis, monopolistis, kolutif, nepotis, represif, sentralistis, dan eksklusif. Semuanya hendak diganti dengan struktur atau paradigma baru yang lebih sesuai dengan tuntutan internal reformasi serta kon- disi eksternal arus globalisasi.

Hampir semua tuntutan yang dikemukakan oleh berbagai golongan dan lapisan masyarakat tersebut disadari atau tidak sebetulnya merupakan satu cara bertindak kolektif yang sama-sama dilandasi oleh satu model berpikir atau strategi intelektual, yang dalam wacana postmodernisme disebut 'dekonstruksi', yakni semacam strategi pembongkaran atau peleburan struktur. Gerakan reformasi mahasiswa tak lain dari gerakan dekonstruksi. Reformasi total yang dikumandangkan sebetulnya adalah kata lain dari dekontruksi total Orde Baru.

Tampaknya begitu banyak struktur bernegara dan berbangsa yang perlu didekonstruksikan. Mulai dari struktur bemegara dan berbangsa. Mulai dari struktur bahasa; politik, ekonomi, sampai pada 'struktur simbolik'.

Dalam karya tulis ini, penulis memaparkan bagaimanakah gerakan reformasi 
yang sedang dan akan terjadi di Indonesia ini dapat dijelaskan secara substansial dengan menggunakan penelaahan secara menyeluruh dan tidak parsial. Untuk melihat hal ini maka penulis menggunakan pendekatan wacana postmodernisme khususnya teori dekonstruksi yang merupakan salah satu wacana postmodernisme yang dikemukakan oleh Jacques Derida seorang filsuf postmodernisme dari Perancis. Wacana Kultur Rezim Orde Baru

\section{Bidang Politik}

Pada level politik formal, konstitusionalisme dan institusionalisme menjadi dua wacana dan praksis terpenting di bawah Orde Baru. Yang pertama ditujukan kepada proses-proses penciptaan format politik yang berbeda dari pendahulunya (Demokrasi Parlementer dan Demokrasi Terpimpin). la adalah semacam proses katarsis dari penyimpangan-penyimpangan dan ketidaknormalan politik masa lalu. Konstitusionalisme lantas menjadi wacana utama dalam politik Indonesia di bawah rezim Orde Baru, yang darinya dapat ditarik berbagai sub-wacana dan sub-praksis politik. Misalnya saja, munculnya berbagai definisi tentang oposisi, hak pilih, kritik politik, dan seterusnya dibuat dengan acuan konstitusional. Demikian pula kasus-kasus seperti cegah tangkal, sensor-sensor pers, film, buku dan sebagainya, juga ditarik dari wacana utama tersebut. (Muhammad A.S. Hikam, 1996: 88).

Sementara itu institusionalisme sebagai wacana dan praksis politik diterapkan untuk menertibkan proses politik dan mengurangi deviasi-deviasi dalam batang tubuh Indonesia. Dari wacana ini diciptakan batasan-batasan tentang apa yang sah dan yang tidak sah dan pengorganisasian kepentingan-kepentingan politik, termasuk digunakannya strategi korporatisme negara bagi penyaluran-kepentingan-kepentingan strategi dalam masyarakat. Kegiatan-kegiatan politik yang dianggap di luar institusi yang sah akan dengan segera ditertibkan seperti misalnya pemogokan, demonstrasi, aksi protes dan sebagainya. Mereka dianggap sebagai praksis-praksis politik yang menyimpang dalam kerangka format politik Orde Baru

Pada tataran ideologis, wacana institusionalisme ditujukan untuk menertibkan perbedaan-perbedaan ideologis dalam masyarakat politik Indonesia yang di masa lampau telah dianggap bertanggung jawab dalam meruyaknya konflik-konflik politik yang pada gilirannya menyumbang bagi suasana chaos di negeri ini, Lewat pelembagaan ideologis ini, negara di bawah rezim Orde Baru semakin memperkuat dasar legitimasinya vis-à-vis masyarakat dan karenanya juga menjadi semakin mantap dalam mengisolasi dan mengikis elemen-elemen ideologis yang bertentangan dengan konsesus. Kategori-kategori seperti ekstrem kiri dan kanan pun diciptakan dalam kerangka memenuhi imperatif stabilitas ini. Pengembangan pelembagaan ideulogis melalui program-program pendidikan, regulasi, disseminasi lewat media massa dan sebagainya, merupakan proses-proses untuk sosialisasi dan internalisasi

Dalam wacana dan praksis institusionalisme politik itu, negara pun memberikan ruang politik yang luas bagi militer untuk semakin berperan, suatu hal yang diperlukan bagi stabilitas. Dengan menggunakan doktrin dwi fungsi ABRI, misalnya, pemahaman peran militer dalam proses sosial dan politik mendapatkan warnanya yang baru yang berbeda dengan pemahaman-pemahaman di Barat, maupun pemahaman liberal yang pernah muncul di Indonesia pada dekade limapuluhan. Militer ditetapkan menjadi bagian yang tak terpisahkan dalam wacana dan praksis politik khas Indonesiá dan memiliki fungsi sebagai stabili- 
sator dan dinamisator.

Struktur sistem politik Orde Baru yang diperkokoh dengan pemberian tempat istimewa kepada Angkatan Bersenjata Republik Indonesia melalui dwi fungsi. Dengan posisi ABRI yang istimewa, dapat dijadikan alat terciptanya stabilitas politik sebagai garda depan yang memperkokoh status quo. Bisa dikatakan bahwa pemerintahan yang kuat dan sanggup melaksanakan programprogram pembangunan tanpa diusik oleh sekian prosedur legislatif yang dipandang cerewet. Dengan klaim yang sah akan urgensi pembangunan ekonomi.

Menurut Mochtar Pabotinggi, stabilitas politik pemerintahan Orde Baru tidaklah tegak di atas dasar yang kokoh. Pemerintah Orde Baru tegak atas dominasi militer, meskipun dominasi demikian memang tidak harus militerisme. Dengan dominasi ini maka ruang lingkup bangsa yang niscaya harus bertumpu di atas dasar kewargaan yang setara mengalami penyempitan yang jauh. Kalangan militer menduduki posisi sebagai warga negara kelas satu dan kalangan sipil sebagai warga negara kelas dua. Dengan mengklaim diri sebagai pengawal setia dari Pancasila dan UUD 1945. Hal ini atas dasar apa yang disebut sebagai ketidakbecusan kalangan politisi sipil di tahun 1950an, dan paroh pertama tahun 1960-an, mereka mengklaim sebagai berhak untuk seterusnya memperoleh privelese-privelese dalam bidang politik. (Mochtar Pabotinggi, 1997: 66).

Secara garis besar dalam perspektif struktural dalam sistem Orde Baru, menurut Franz Magnis Suseno terdapat dua kekurangan, pertama, tidak adanya kontrol efektif terhadap pemerintahan; kedua, defisit kehidupan demokratis. (Franz Magnis S, 1997: 14).

Mengenai hal kontrol eksekutif: disini tidak disangkal bahwa diatas kertas ada pelbagai lembaga kontrol. Tetapi sulit diban- tah bahwa kenyataan pemerintah Orde Baru dapat memutuskan kebijakan-kebijakannya dengan tidak perlu memperhatikan pandangan dari luar dirinya sendiri. MPR, BPK, DPR, pers dan pendapat umum lain, ungkapan sikap masyarakat seperti unjuk rasa, semua itu sedikitpun tidak bisa menghambat kehendak pemerintah. Maka pemerintah tidak berada di bawah kontrol selain kontrol dirinya sendiri dan tidak dapat dituntut pertanggungjawabannya selain atas hal dan dengan cara yang dikehendaki sendiri.

Akibatnya, sejak permulaan tahun 70an sudah tampak gejala salah management, korupsi, kemudian nepotisme, kolusi, dan pergeseran kriteria prestasi dengan koneksi. Proyek-proyek pembangunan tertentu tidak dapat disorot, apalagi dikritik. Kepentingan umum semakin termakan oleh kepentingan pribadi dan distingsi itu sendiri semakin tidak jelas lagi. Pelanggaranpelanggaran pelbagai hak asasi manusia tidak dapat diusut. Berkembanglah budaya top down total berlaku. Dengan demikian ketidaksamaan, kesenjangan sosial, inefisiensi dan ekonomi biaya tinggi semakin jadi dan kebijakan-kebijakan yang tampak irrasional, dalam arti tidak berani dibuka terhadap sorotan para ahli, semakin terakumulasi.

Yang kedua, yang periu dibedakan dari yang pertama meskipun berkaiatan erat dengannya (karena kontrol tanpa lembaga demokratis tidak mungkin), adalah defisit kedemokratisan kehidupan politik. Dengan Golkar terjamin kemenangannya serta dua partai politk tidak mampu menentang kebijakan pemerintah, dengan konsep "kebebasan yang bertanggung jawab" dalam penerapan kebebasan untuk menyatakari pendapat, dan dengan banyak kebijakan lain, sudah terjamin bahwa pemerintah memang tidak dapat diganggu gugat dalam pembangunan. Kesimpulannya, demokrasi ditulis 
dengan huruf kecil. Maka masyarakat sebagian besar menjadi objek perencanaan pembangunan, ia tidak sempat mengartikulasikan aspirasi, harapan dan kritik. Kenyataannya pembangunan Orde Baru tidak berhasil menciptakan struktur-struktur yang memungkinkan partisipasi nyata masyarakat dalam penentuan arah pembangunan.

Maka dua kelemahan struktur managemen kekuasaan Orde Baru cukup jelas; tidak adanya mekanisme kontrol efektif menghasilakan penumpukan birokrasi, korupsi, dan inefisiensi. Sedangkan managemen top down tidak membuka saluran ekspresi aspirasi dan konflik yang hidup. dalam masyarakat dan tidak memungkinkan perkembangan tanggung jawab sosial yang nyata, situasi mana dengan sendirinya mempertajam ketegangan antara golongan dan memusatkan perhatian pada wilayah yang tidak dikuasai pemerintah, loyalitas-loyalitas primordial.

\section{Bidang Ekonomi}

Dalam perspektif sistem dalam bidang ekonomi Orde Baru, sasaran yang ditujukan adalah pembangunan ekonomi sebagai landasan kehidupan masyarakat yang aman, makmur, adil, berdasarkan Pancasila. Namun, kebijakan yang diambil untuk mencapai sasaran itu, sama dengan semua kebijakan manusia, sejak semula juga mempunyai beberapa kelemahan struktural. Kelemahan-kelemahan itu diabaikan, barangkali karena dianggap sebagai harga yang harus dibayar untuk mencapai tujuan utama pembangunan tadi

Untuk menelusuri dengan lebih térinci perjalanan kebijakan ekonomi Orde Baru, ada lima kebijakan Orde Baru yang memainkan peranan kunci. Semua lima kebijakan itu bersifat ambivalen karena satu pihak mempunyai suatu rasionalitas objektif, di lain pihak suatu kelemahan moral.

Lima kebijakan ini secara garis besar yang dikemukakan oleh Franz Magnis Suseno adalah sebagai berikut, pertama, pragmatisme dalam menentukan kebijakan pembangunan; kedua pola pembangunan top down; ketiga orientasi pada pertumbuhan; keempat bersandar pada beberapa pengusaha besar, terutama yang keturunan Cina; kelima kepentingan pribadi para keluarga pejabat semakin merajalela. (Franz Mgnis Suseno, 1998: 9).

Pertama, kebijakan dasar dasar pemerintahan Orde Baru memilih pendekatan pragmatis dalam pembangunan. Maka "Sosialisme Indonesia" yang telah memporakporandakan perekonomian di negara Indonesia dibuang dan Pasal 33 UUD 1945 diintepretasikan secara longgar. Pókoknya, Indonesia terangkat secepat mungkin dari jurang kehancuran serta ditempatkan kembali pada dasar ekonomi yang sehat.

Kedua, pada era'Orde Baru berpendapat bahwa model pencarian konsesus demokratis dinilai akan mempersulit pengambilan keputusan-keputusan berani yang perlu, Orde Baru memilih pola pembangunan top down. Dalam hal ini mereka juga mengingat ketidakmampuan pemerintah-pemerintah masa demokrasi parlementer tahun 50-an untuk mengambil tidakan-tindakan reformasi ekonomi.

Sebagai implikasi pendekatan top down itu, perwujudan demokrasi di Indonesia harus ditunda. Suatu harga yang tampak wajar demi pengembalian kesehatan ekonomi bangsa, namun membawa akibat Orde Baru tidak berhasil dalam pembangunan kehidupan politik.

Kebijakan dasar ketiga Orde Baru adalah prioritas pertumbuhan terhadap pemerataan. Kebijakan itu berdasar argumen bahwa "kue harus dibuat dulu, baru bisa dibagi". Semboyan ini sudah dibantah pada permulaan tahun 70-an dengan argumen bahwa kalau pembagian tidak dijangkarkan di dalam pembuatan kue itu sendiri, kue 
itu tidak pernah akan dibagi.

Sébagai kerangka teoritis Orde Baru memimilih teori Walt $W$. Rostow di mana masyarakat berpendapatan rendah diharapkan akan kebagian dalam pertumbuhan lewat apa yang disebutnya trickle down effect. Pertumbuhan kuat juga sangat diperlukan sebagai landasan ketahanan nasional. Hanya perekonomián yang kokoh dapat menghasilkan dana yang diperlukan oleh pemerintah untuk menjalankan tugastugasnya, termasuk menjamin tugas-tugasnya, termasúk menjamin pemenuhan kebutuhan pokok masyarakat.

Namun meskipun kemiskinàn berhasil sangat dikurangi, prioritas pada pertumbuhan menjadi dasar masalah terbesar yang dihadapi; kesenjangan antara tidak lebih dari 30 persen masyarakat yarig terlibat dalam spiral gerak pembangunan ke atas, dan yang̉ 70 persen lagi yang, meskipun barangkali sudah tidak miskin , tetap hidup pas-pasan dan menjadi penonton "kema.juan pembangunar".

Tambahan pula, prioritas pada pertumbuhan mempunyai akibat bahwa dengan sendirinya kepentingan orang kecil cenderung diremehkan bahkan dikorbankannya. Segala macam penggușuran orang kecil dari rumah dan tanah demi proyek-proyek besar, banyak yang tidak produktif melainkan demi konsumsi golongan beruang, dibenarkan dengan argumen bahwa penggusuran semacam itu akhirnya juga akan meningkatkan perekonomian golongan berpendapatan rendah.

Kebijakan keempat adalah pimpinan rezim Orde Baru memilih pengusaha-pengusaha keturunan Cina sebagai pendukuing utama pembangunan. Para pengusaha keturunan Cina ini memang terbukti mampu miengakumulasikan modal dań mengembangkan usaha. Dalam rangka pragmatisme pembangunan masuk akal pemerintah Orde Baru memanfaatkan naluri dan ke- pentingan bisnis mereka untuk memotori pembangunan. Namun kebijakan ini mempunyai konsekuensi negatif yang cukup besar. Yaitu tumbuhnya apa yang disebut "ékonomi koneksi". Dengan ekonomi koneksi maka korupsi, sistem "ambil persen", "katabelece", sogok dan sebagainya mulai merajalela. Dengan demikian," próduksi Indonesia menjadi semakin mahal dan semakin tidak dapat bersaing di pasar global.

Akibat negatif selanjutnya adalah terbèntuknya konglomerat-konglomerat yang semakin raksasa. Pendekatan "koneksi". cenderung mendahulukan mereka'yang didahulukan lebih dulu dan karena itu menciptakan konglomerasi kekuasaan ekonomi yang semakin eksklusif. Padahal perekonomian berdasarkan konglomerasi itu secara ekonomis tidak sehat, terutama karena kurang transparan dan kurang inovatif; efisiensi tiap-tiap unit mudah menjadi kabur dan reaksi konglomerat atas perubahan di pasar biasnya lamban dan kaku.

Berpusatnya ekonomi pembangunan pada beberapa konglomerat menjadikan elite ekonomi yang berkoneksi dengan elit kekuasaan politik dan beruntung dari pertumbuhan ekonomi nasional bersifat eksklusif dan tertutup: yang belum termasuk tidak akan termasuk. Pada akhirnya konsentrasi kekuasaan ekonomi secara mencolok dalam tangan segelintir orang keturunan Cina dapat membuat situasi sosial menjadi rawan, dan itu terbukti.

Kebijakan terakhir dalam bidang ekonomi oleh rezim Orde Baru adalah bahwa semakin banyak proyek anggota keluarga pejabat dilibatkan. Proyek-proyek besar dan yang menjanjikan banyak keunitungan semakin tidak akan jalan, kecuali seorang anak pejabat duduk dalam pimpinan dan ikut memilikinya. Oleh karena itu, para pengusaha besar meminjam atau mengkooptasi anak pejabat sebagai partner, lalu hadangan birokrasi dapat didobrak. 
Apa akibat samping negatif kebijakan ini? Pertama, elite ekonomi semakin eksklusif lagi; jumlah mereka yang mempunyai akses ke proyek-proyek besar semakin sedikit, kekuasaan ekonomi semakin terkonsentrasi daiam tangan beberapa "anak" pejabat dan konglomerat yang berkoneksi dengan mereka.

Kedua, efisiensi ekonomis semakin tidak menjadi pertimbangan lagi dalam perwujudan proyek besar. Asal ada anak pejabat tinggi terlibat, semua pertimbangan kelayakan ekonomi, peraturan dan birokrasi akan dikesampingkan dan seperlunya juga diberi proteksi. Akhirnya akibat dari itu semua ekonomi Indonesia semakin mahal, tidak efisien dan mengalami kekeroposan.

Pada akhirnya pamrih dan kesombongan penguasa membuat seluruh sistem pembangunan semakin lemah dalam mewujudkan apa yang menjadi. legitimasinya; perwujudan dasar-dasar kehidupan seluruh bangsa Indonesia yang sejahtera, adil, dan sesuai dengan martabat mereka sebagai manusia. Sebagai akibat kombinasi pragmatisme, peremehan terhadap pertimbangan keadilan dan sikap tidak peduli akan nasib orang kecil dan bangsa terancam bukan hanya kebangkrutan moral juga kebangkrutan ekonomi.

\section{Bidang Hukum}

Menurut Donald KEmerson sistem politik Indonesia dapat dijelaskan dalam pendekatan budaya, bahwa sistem politik yang tidak demokratis di Indonesia itu disebabkan oleh bekerjanya budaya patrimonial atau paternalistik yang melahirkan yang melahirkan" politik yang bersifat "patron clien". (Moh. Mahfud MD, 1998: 4).

Dengan asumsi bahwa hukum merupakan produk politik, maka dengan sendirinya budaya hukum juga menjadi begitu berorientasi ke atas atau berwatak elitis dan orotodoks atau konservatif. Hukum- hukum di Indonesia tidaklah merupakan hukum yang bersumber dari aspirasi masyarakat bawah melainkan lahir dari ats yang penegakkannya juga sangat bergantung dari atas. (Moh Mahfud. MD, 1998: 6).

Watak hukum yang konservatif menurut Moh Mahfud MD ditandai oleh hal-hal sebagai berikut: pertama, proses pembuatan yang konservatif ini selalu berasal dari atas, tidak mellyerap aspirasi politik atau kesadaran hukum masyarakat sebagai bahan materialnya. Karena hukum yang lahir tidak bersumber dari kenyataan dan kebutuhan masyarakat yang dilayaninya seringkali hukum itu juga jauh dari masyarakatnya. Biasanya gagasan-gagasan pembentukan hukum lahir dari kehendak politik pemerintah sedangkan wakil-wakil rakyat tinggal menyetujuinya sehingga DPR itu lebih merupakan semacam "rubber stamp" atau stempel karet. (Moh Mahfud MD, 19-98: 6).

Kedua, jika dalam pembuatannya hukum itu selalu bersumber dari atas maka isinyapun lebih merupakan pembenaran terhadap apa yang telah atau akan dilakukan oleh pemerintah. Di sini hukum bersifat "positivistik instrumentalistik" dalam aiti memuat isi yang memberi justifikasi bagi apa yang bagi apa yang telah atau dilakukan sebagai program negara. (Moh Mahfud $M D, 1998: 6)$.

Ketiga, karena bersifat elitis maka hukum dijadikan alat kekuasaan atau kewenangan yang sangat besar kepada pemerintah Orde Baru untuk mengatur lebih lanjut berbagai ketentuan-ketentuan UU dengan peraturan yang lebih rendah secara hierarkis. Di dalam ilmụ hukum kewenangan yang demikian ini disebut atribusi kewenangan dan delegasi kewenangan. Dengan atribusi kewenangan ini pemegang kekuasaan kemuadian mengeluarkan berbagai peraturan lanjutan yang biasanya lebih merupakan kehendak sepihak dari pemerintah dan kerapkali menghilangkan atau menga- 
burkan makna substantif peraturan yang mendasarinya. (Moh Mahfud MD; 1998: 7).

Hukum yang berorientasi ke atas itu telah pula membawa bangsa Indonesia pada budaya penentuan sumber hukum material yang baru yakni pernyataan pejabat. Biasanya keinginan, pernyataan, atau sikap pejabat diperlakukan sebagai hukum atau sesuatu yang imperatif.

\section{Postmodernisme}

Pertanyaan, apa itu postmodernisme, membuahkan banyak jawaban. Bukan saja karena banyak orang yang mengajukan jawaban yang berbeda-beda bahkan bertentangan. Ada sebab yang lebih penting, yakni postmodernisme itu sendiri (seperti halnya modernisme) memang bersifat jamak dan majemuk. Tidak tunggal. Bahkan Kamus The Modern-Day Dictionary of Received Ideas merumuskan "Postmodernisme" adalah: "Kata ini tidak punya arti. Gunakan saja sesering mungkin"

Salah satu rumusan umum dan sederhana menggambarkan postmodemisme sebagai sebuah pemberontakan terhadap modernitas global sesudah Perang Dunia II yang berpusat di Barat (khususnya Amerika Serikat). (Ariel Heryanto, Kompas, 1994). Dalam bidang filsafat istilah postmodernisme menunjukkan segala bentuk refleksi kritis atas paradigma-paradigma modern. (I. Bambang Sugiharto, 1996: 28).

Modernitas paruh kedua abad ini ditandai oleh keyäkinan fanatik pada sejarah perkembangan sosial secara linier, kebenaran ilmiah yang dimutlakkan, dan rekayasa manusia bagi suatu tatanan dunia yang diidealkan.

Berjayanya modernitas yang berpusat dan dikuasai Barat itu, memungkinkan legitimasi proyek "modernitas" di berbagai kawasan dunia. Hasilnya telah direkayasa sebagai pembangunan yang berwatak ser- ba menyeragamkan, materialistik, teknokratik, dan rasionalistik. Sebagai lawannya postmodernisme mempraktekkan budaya tanding, dengan mengandalkan hal-hal yang terkandung dalam rahim.

Maka postmodernisme pertama-tama ditandai oleh hilangnya keprcayaan pada modernitas seperti kemajemukan, partisipasi, keterbukaan, proses, plesetan, ketidakpastian proyek modernisasi.

Maka postmodernisme pertama-tama ditandai oleh 'hilangnya kepercayaan pada proyek modernisasi. Gugatan pertama diajukan kepada pentolan ilmu pengetahuan terhadap kekayaan dimensi manusia dan perkembangan masyarakat. Sifat kepastian dan universalitas dari ilmu pengetahuan ataupun ideologi modem itu dipertanyakan. Sementara kultur non ilmu, seperti tradisi lama yang banyak mengajari kearifan hidup dibangkitkan kembali. (Denny, J.A., Kompas, 1994).

Terhadap kepastian modernitas, postmodernisme mengajukan berlakunya sifat misteri dalam psikologi manusia maupun pertumbuhan peradaban yang tidak dapat dikontrol sepenuhnya oleh ilmu pengetahuan, dan karenanya menjadi bahaya jika ilmu mencoba mengontrolnya. Di tingkat kosmologi, postmodernisme menunjukkan, bahwa semesta tidaklah bersifat mekanik dan deterministik, tapi evolusionis yang tidak dapat ditebak arah perkembangannya. Terhadap arah universalitas ilmu dan ideologi sosial, postmodernisme mengajukan relativisme dan pluralisme

Dari sudut pandang filsafat, maka karakter yang khas dalam modernisme adalah, bahwa ia selalu berusaha mencari dasar segala pengetahuan (episteme, Wiisenschaft) teantang "apa"nya (ta onta) realitas, dengan cara kembali ke subjek yang mengetahui itu sendiri (dipahami secara psikologis maupun transendental). Di sana diharapkan ditemukan kepastian men- 
dasar bagi pengetahuan kita tentang realitas itu, realitas yang biasanya dibayangkan sebagai "realitas luar". Kepastian itu per-sisnya terdapat dalam hukum logika. Jadi, kalau saja kita bisa mengorganisasikan gagasan-gagasan logis tepat, maka langsung pula didapatkan "representasi" yang benar atau keserupaan "obyektif" dengan kenyataan. Demikian "Fondasionalisme" dan "Representasionalisme" telah menjadi sebutan bagi paham yang berkembang sejak Descartes hingga filsafat Analitik abad keduapuluh itu. Dalam peristilahan Heidedger, karakteristik kemodernan yang menonjol adalah adalah bahwa dunia menjadi semacam gambar atau representasi, sekaligus manusia menjadi diantara lautan objek. Atau dalam peristilahan Merleu-Ponty, manusia menjadi kosmotheoros, alias penonton murni, dan pada saat yang sama dunia menjadi le Grand Objet. (I. Bambang Sugiharto, 1996: 35).

Dalam modernisme, filsafat memang berpusat pada Epitemologi, yang bersandar pada gagasan tentang subjektivitas dan objektivitas murni, yang satu sma lain terpisah tak saling terkait. Tugas pokok filsafat adalah mencari fondasi segala pengetahuan (Fondasionalisme), dan tugas pokok subjek adalah mempresentasikan kenyataan objektif (Representasionalisme).

Demikian maka klaim-klaim dari kaum postmodernisme tentang "berakhirnya Modernisme" biasanya dimaksudkan untuk menunjukkan berakhirnya anggapan modern tentang "subjek" dan "dunia objektif" tadi, dunia yang seolah sepenuhnya mandiri menanti subjek yang akan membuat representasi mental tentang nya saja. Lalu postmodernisme dimengerti sebagai upayaupaya mengungkapkan segala konsekuensi. dari berakhirnya modernisme itu berserta metafisika tentang fondasionalisme dan representasionalismenya

Secara lebih positif postmodernisme, menurut Jo Verhar dapat dijelaskan sebagai berikut. Pertama, pengetahuan ditihat sebagai keseluruhan dari apa yang kita ketahui (juga dan khususnya, secara specialistis) sebagai sesuatu yang pragmatis. Artinya, bila pengetahuan menolong kita untuk mencapai tujuan kita hal itu sudah cukup. Segala bentuk pengetahuan menolong tertanam dalam "paradigma" tertentu yang tidak dapat dibuktikan merupakan paradigma mutlak, dan yang akan diganti di kemudian hari oleh paradigma yang lain lagi (Jo Verhar, Basis, 1997: 74).

Kedua, identitas manusia dapat dilambangkan dengan banyak cara. Ada yang "pramodern", misalnya "jiwa" sebagai "forma" tubuh atau bahkan dua forma atau lebih untuk makhluk yang sama. Identitas manusia selamanya harus ditentukan wujudnya lagi menurut budaya, menurut tradisi, menurut perlawanan terhadap tradisi atau budaya, menurut riwayat hidup tiaptiap orang, dan demikian seterusnya (Jo Verhar, Basis: 1997:74-75).

Ketiga, interioritas manusia dapat dipahami sebagai pemusatan pengaruh keaktifan dan keemosialan dalam satu "pusat" yang dianggap tidak selalu harus atau bahkan dapat menjadi kentara secara lahiriah. Menurut kaum postmodernisme, intuisi sebagai pengetahuan tidak luput dari dari dualisme. Pengetahuan kita tertanam dalam bahasa. Bahkani, pikiran tidak lain adalah bahasa yang merumuskannya: Asas postmodern tidak ada apa-apa di luar bahasa. Bahasa juga tidak dapat dianggap "mencerminkan" realitas. (Jo Verhar, Basis, 1997: 1997:75).

Keempat, pencarian kepastian lahir dari keinginan untuk mengatasi skeptisisme. Keinginan tersebut berasal dari rasa cemas. Dalam kerangka postmodern, skpetisisme tidak menjadi soal., karena manusia adalah makhluk kecil, makhluk yang terbatas. Dan skeptisisme dapat membuka jalan un- 
tuk tak terduga. Kepastian menutup semua pintu. (Jo Verhar, Basis, 1997: 75).

Postmodernisme beranggapan bahwa logika berasal dari bahasa biasa, tak ada proses rasional universal, atau bahasa universal. Karena itulah postmodernisme sering dipandang sebagai "relativis". Karena secara postmodernisme "kebenaran" adalah sifat dari pernyataan, dan pernyataan terlaksana dalam bahasa, dan bahasa itu adalah "kontingen" seperti manusia itu sendiri.

Postmodernisme juga ditandai apa yang disebut dengan de-diferensiasi.. Artinya adalah sebuah periode di mana batas-batas tadi semakin samar. Segala bentuk dikotomi menjadi sangat problematik karena semua serba tercampur. Berbeda dengan, modernisme yang ditandai dengan "diferensiasi" atau pemaknaan yang bersifat dikotomis. Diferensiasi bisa dilihat diljhat melalui jelasnya batas-batas antar bangsa, antaragama, antarras, antarsuku, dan antar golongan. Ini bisa menjelaskan mengapa sejumlah pihak membuat tembok pembatas antara dirinya dengan orang lain. Dikotomi sosialisme-kapitalisme, Timur-Barat, negara maju-negara berkembang, kulit putih - kulit berwarna adalah contoh-contoh yang bisa memberikan legitimasi terhadap ide diferensiasi

\section{Dekonstruksi Jacques Derrida Sebagai Wacana Postmodernisme.}

Ketika pembicaraan tentang postmodernisme maka, tidak akan terlepas pada salah tokoh utama kaum postmodernisme yakni Jacques Derida. Pangkal keprihatinan Derida pada filsafat modernisme adalah konsep universalisme. Bagi Derida pada konsep universalisme pada akhirnya akan men-"diam"-kan otherness dan perbedaan. Universalisme sendiri berbasis pada filsafat dan metafisika Barat. Para filsuf Barat, dari Plato sampai Rousseau, dari Descartes sampai Husserl masih dikungkung oleh tradisi berpikir "logosentrisme".

Ciri yang menonjol dari tradisi logosentrisme ini adalah adanya kecenderungan berpikir oposisi biner yang bersifat hierarkis (esensi/eksistensi, substansi/aksidensi, jiwa /badan, makna/bentuk, transenden/empiris, positif/negatif, bahasa lisan/bahasa tulisan dan seterusnya) dengan anggapan bahwa yang pertama adalah pusat, asal muasal, fondasi, prinsip, dan ada secara niscaya; sedang yang kedua hanya sebagai derivasi, manifestasi, pinggir, dan sekunder dalam kaitannya dengan yang pertama. Sejarah filsafat Barat, kata Derika adalah sejarah "pergantian dari satu pusat ke pusat lain, meski dengan nama dan bentuk yang berbeda-beda. Adanya pemusatan inilah yang mendorong filsafat Barat cenderung totaliter sehingga yang bukan pusat, yang partikular yang lain, yang berbeda harus disubordinasikan ke dalamnya.(Ahmad Sahal, Kalam, 1994: 19).

Mencermati hal itu Derida lantas melakukan strategi dekonstruksi. La deconstruction pertama kali dibakukan oleh Derida dalam bukunya De La Grammatologie (1967). Istilah dekonstruksi yang dipakai Derida adalah pinjaman dari Heidedger, hanya saja Derida membubuinya dengan beberapa resep linguistik dan metode gramatologi ciptaannya. la menerapkan metode ini dalam metafisika Barat klasik, dimului dari Plato dan berakhir di tangan Heidedger. Derida mengklaim kerelativitasan metafisika, walau hampir semua filsuf pra Heidedger mengagungkan pembahasan tersebut. Dekontruksi menurut Derida adalah sebagai alternatif untuk menolak segala keterbatasan penafsiran ataupun bentuk kesimpulan yang baku. (Luthfy Assyaukanie, 1994: 25).

Perlu ditegaskan bahwa dekonstruksi tidak tepat jika diartikan secara harafiah 
sebagai "membongkar" apalagi "menghancurkan" sehingga yang tersisa tinggal monisme atau bahkan kekosongan. Dekonstruksi juga bukan metode tafsir yang dilengkapi dengan piranti-piranti konseptual yang serba argumentatif dan koheren. Bahkan justru dekonstruksi, anti argumentatif, dan anti koherensi, kalau yang dimaksud dengan meode, argumentasi dan koherensi adalah sesuatu yang berbau ilmiah dan positivistik. Dekonstruksi, pertama sekali, adalah usaha membalik secara terus menerus hierarki oposisi biner tersebut dengan mempertaruhkan bahasa sebagai medannya. Dengan demikian, yang semula pusat, fondasi, prinsip dipelesetkan sehingga berada di pinggir, tidak lagi fondasi, dan tidak lagi prinsip. Strategi pembalikan ini dijalankan dalam kesementaraan dan ketidakstabilan yang permanen sehingga bisa dilanjutkan hampir tanpa batas. (Ahmad Sahal, Kalam, 1994: 19-20).

Strategi dekonstruksi dijalankan dengan asumsi bahwa filsafat Barat bisa mempertahankan ide tentang pusat sebagai kehadiran murni hanya dengan cara menekan efek-efek metaforis dan figuratif yang menjadi karakter bahasa. (Christopher Norris, 1982: 18).

Karena terpanggil untuk sampai pada kebenaran absolut, filsafat lantas menunggalkan pengertian bahasa yang dipakainya dengan menyusun konsep dan teori yang kokoh secara argumentatif. Filsafat percaya bahwa konsep dan teori mampu mempresentasikan kebenaran seperti apa adanya. Oleh karena itu, praksis dan etika kehidupan publik manapun harus mendasarkan dirinya diatas konsep filosofis yang kuat klaim kesahihannya.

Dekonstruksi justru memberontak terhadap penunggalan ini. Dekonstruksi hendak memunculkan kembali dimens-dimensi metaforis dan figuratif dari bahasa dan membiarkan bahasa dalam karakternya semula, yaitu yang bersifat polisemi, ambigu dan serba paradoks dalam dirinya sendiri. Dengan mengurai kembali ambiguitas bahasa, maka filsafat tidak lagi punya alasan untuk berkorespondensi dengan kebenaran. Sebab, bahasa sebagai sarana pengungkapan bersifat subversif terhadap dirinya sendiri. Bahasa tidak pernah bisa dipercaya. Filsafat, dengan demikian, harus segera menyadari bahwa otoritasnya sampai pada kebenaran bisa dengan mudah dijungkirbalikkan oleh bahasa. Dalam kaitannya, dengan ini, Derida sendiri pernah bilang bahwa "sejarah filsafat Barat tidak lebih dari sejarah metafor dan metonimi".(Ahmad Sahal, Kalam, 1994: 20).

Implikasi dari dekonstruksi filsafat adalah lumernya batas-batas yang selama ini dipertahankan secara keras antara konsep dengan metafor, antara kebenaran dengan fiksi, antara filsafat dengan puisi, antara keseriuasan dengan permainan. Pembedaan seperti ini, tak ragu lagi, adalah berpikir logosentris. Dengan membaca secara dekonstruktif kita bisa mengatakan bahwa bagian pertama dari masing-masing pasangan tersebut menempati posisi pusat dan pertama karena bagian lainnya dipinggirkan, dikeluarkan dan disnggap sebagai "yang lain" Namun sang pusat mendapatkan kepenuhan identitas justru dengan cara membedakan dirinya dengan, dan mengeluarkan diri dari "yang bukan pusat", dari "yang bukan di dalam". Pusat dengan demikian sepenuh-penuhnya membutuhkan "yang lain", yang berada di pinggir yang berada "di luar" sebenarnya (juga) "sangat di pusat", "sangat di dalam".

Karena "yang dipinggir" dan "yang di luar" sebenarnya sangat di pusat dan di dalam, maka tidak berlebihan kalau kita mengatakan bahwa konsep adalah metafor (juga), kebenaran ternyata tidak kurang fiksinya, filsafat adalah sejenis puisi, dan keseriusan tidak lain adalah permainan. Se- 
muanya berada dalam medan yang sama, yakni bahasa, dengan makna yang selalu ditunda, yang ambigiu, paradoks, dan selalu berada dalam diseminasi. Dengan kata lain, bahasa (juga realitas, karena realitas tidak mungkin hadir tanpa bahasa) merupakan "teks", "tulisan", dengan kemajemukan pengertian yang tidak mungkin dirujukkan kepada suatu asal-usul yang tunggal dan baku.

Dekonstruksi mencoba untuk meletakkan kembali strukturalitas struktur yang ada di dalam fluiditasnya semula, yakni dalam lanskap permainan di mana pusat dan batas-batas belum lagi mengeras. Dengan begitu, pluralitas dan heteregonitas kehidupan kembali terhampar.

\section{Dekonstruksi Kultural Rezim Orde Baru.}

Dekonstruksi sebagai strategi intelektual dalam menghancurkan, meruntuhkan, membongkar, menguak, atau meleburkan setiap jenis struktur (bahasa, ideologi, ekonomi, politik, hukum, dan kebudayaan), yang selama ini (dipaksa untuk) diterima sebagai satu "kebenaran", sehingga tidak menyisakan ruang bagi pertanyaan, gugatan atau kritikan. Struktur yang telah didekontruksikan tersebut kemudian direkonstruksikan kembali, untuk menghasilkan struktur (-struktur) baru yang lebih segar, lebih demokratis, lebih terbuka. Inilah sebetulnya hakikat reformasi struktural.

Kekebalan struktur (bahasa, ideologi, ekonomi, politik, hukum dan kebudayaan) Orde Baru pada era reformasi diserang, dipertanyakan atau dikritik, pada dasarnya disebabkan oleh beroperasinya semacam prinsip yang oleh Jecques Derida disebut "logosentrisme" pemikiran di dalam struktur-struktur tersebut, yakni klaim akan "kebenaran yang pasti benar" yang melandasi pikiran, bahasa, dan tindakan-tindakan.
Logosentrisme, dalam bahasa William Liddle disebutkan bahwa Rezim Orde Baru ditentukan lewat sebuah ideologi yang disebut dengan 'populisme birokrasi' dengan 'hierarki dan pertahanan' adalah "sesuatu yang dilegitimasikan sebagai semacam sabda agung atau kerakyatan yang dipimpin oleh hikmah..." Ini adalah harmoni ideologi dan kebijakan yang tegas menekankan sebuah kesatuan organik atau $\mathrm{Ne}$ gara Korporatis Organik di mana segenap sudut masyarakat secara fungsional diatur untuk menudukung pembangunan ekonomi. Walhasil, dalam membangun simbol $\mathrm{Ne}-$ gara masyarakat diintegrasikan ke dalam organisasi negara yang dicetuskan sebagai persatuan nasional. (Michael van Langenberg, 1996: 225).

Dengan karakter yang logosentrisme, maka kontrol negara lalu mengambil peran melalui interaksi antara sistem negara dan masyarakat madani, yang mana pasangsurutnya ditentukan oleh derajat kesepakatan hegemonik. Elite dan massa membutuhkan semacam pengertian bersama mengenai model dan citra negara manakala struktur hegemoni tengah beropersi. Struktur dominasi dipahami secara persis kecuali jika ketotalan 'integralistik' dari negara yakni negara sebagai 'ide' (ideologi) dan 'instrumen' (sistem /kebijakan) berinteraksi dengan struktur dan proses kekuasaan, legitimasi dan akumulasi. Sedangkan ciri yang sentralistik dengan menolak secara total "yang lain" dari sistem Orde Baru adalah bersifat Oligarki. Pada dasamya negara berada di bawah perintah sebuah oligarki di sekeliling Presiden Soeharto. Dan inti dari jaringan oligarki kepemimpinan itu ada di tangan lembaga kepresidenan, yang terkait dengan seluruh lembaga kunci menangani kontrol dan manajemen negara: kebijakan, mobilisasi dan keamanan.

Kecenderungan 'logosentrisme' di dalam pemikiran Orde Baru juga ditandai de- 
ngan beroperasinya semacam prinsip oposisi biner sebuah struktur bahasa, sosial, politik ekonomi dan budaya, yang dibangun oleh pasangan-pasangan konsep yang saling berseberangan, yang hubungannya dianggap sebagai satu harga mati yang tidak tidak dapat disentuh (untouchable).

Struktur politik Orde Baru pada hakikatnya dibangun oleh pasangan-pasangan konsep oposisi biner ini, yang digunakan sebagai alat untuk mempertahankan status quo kekuasaan. Pasangan-pasangan konsep seperti pancasilias/antipancasila, komponen bangsa/perusuh, konstitusional/ inkonstitusional, pahlawan/pembangkang, progresif/subversif, pemersatu bangsa/pemecah belah bangsa, aparat pemerintah/ oknum tidak bertanggung jawab, adalah pasangan-pasangan konsep yang digunakan di dalam struktur politik (atau depolitisasi) Orde Baru.

Di dalam peta oposisi biner tersebut di atas, pasangan-pasangan konsep tersebut dikonstruksikan sedemikian rupa, sehingga konsep-konsep yang pertama seolah-olah merupakan hak istimewa (privilage) pihak penguasa, sedangkan konsepkonsep kedua merupakan milik pihak-pihak yang menentang kekuasaan. Pihak-pihak yang berseberangan dengan penguasa digeneralisir sebagai: antiparicasila, antipembangunan, inkonstitusional, oknum tidak bertanggung jawab, dan sebagainya.

Di sini sistem politik Orde Baru menciptakan seperangkat "kontruksi semu realitas sosial" dengan memanipulasi makna dan realitas yang diterima oleh masyarakat sebagai satu "kebenaran", sesungguhnya tidak lebih dari sebuah 'distorsi realitas'.

Dominasi sebuah kekuasaan sentralistik pada Rezim Orde Baru atas masyarakat, mengandaikan adanya sebuah struktur hierarkis penafsiran, yang menempatkan lembaga kepresidenan yang dominan itu pada posisi "pusat" dan menempatkan "yang lain" (the other) pada posisi "pinggir" (peripheri). Struktur hierarkis ini tidak hanya mengeksklusi "yang lain" dalam hal ini masyarakat, namun juga menundukkan, mensubordinasikan dan merepresinya. Maka diperlukan suatu strategi untuk pembalikkan struktur hierarkis penafsiran itu, guna melakukan delegitimasi atas klaim "pusat", "origin", dan "primer" dari diskursus maupun praksis yang dominan. Strategi ini adalah dekonstruksi.

Dekontruksi kuitural terhadap rezim Orde Baru adalah nama yang digunakan untuk sebuah tindakan kritis yang melaluinya berbagai bentuk oposisi biner di dalam berbagai wacana budaya politik, ekonomi, hukum, komunikasi, secara parsial maupun total dibongkar atau dileburkan untuk sebuah kebudayaan yang telah keropos, bagi terciptanya wilayah baru regenerasi-budaya.

Dekonstruksi kultural dimaksudkan untuk meleburkan hierarki makna yang dihasilkan oleh struktur-struktur kultural warisan Orde Baru yang feodalistis, mono-polistis atau represif. Karenanya, setelah peleburan tersebut, tidak ada lagi klaim bahwa satu kelompok lebih pancasilais dibandingkan kelompok lainnya, sebuah kelompok lebih berjiwa pembangunan dibandingkan kelompok lainnya. Sebab klaim demikian itu tidak labih dari intrepretasi sepihak belaka.(Yasraf A.P, Kompas, 1998).

Peleburan struktur hierarkis penafsiran, maka dekonstruksi menempatkan, negara dan masyarakał, pemimpin dan yang dipimpin dalam posisi yang sejajar, co-existensi. Dominasi yang dileburkan atau ditundukkan dapat meruntuhkan peran legitimasi dan justifikasi relasi-relasi kuasa represif yang ditopang oleh penafsiran tunggal. Karena relasi kuasa tidak dapat bertahan tanpa adanya wilayah "yang lain" yang menopangnya, maka relasi-relasi kuasa yang represif itu akan dapat ditransformasikan menjadi relasi-relasi kuasa dalam bentuk- 
nya yang positif.

Pada titik ini, dekonstruksi dapat dipahami sebagai "an openess towards the other", "keterbukaan kepada yang lain". Pernyataan ini tidak hanya mencirikan karakter yang paling penting dari dekonstruksi sebagai sebuah strategi, namun bisa digunakan sebagai arahan untuk membangun suatu sikap, ethos, dan pandangan dunia postmodern yang egaliter, dengan menekankan prinsip ko-eksistensi antar beragam entitas-entitas, baik politik, ekonomi, hukum dan sebagainya, yang menjadi unsur pembentuk dunia di mana kita hidup ini. (Rudy Harisyah Alam, 1994: 34).

\section{Indonesia Menuju Paradigma Baru}

Dengan menyadari sepenuhnya bahwa sejarah bangsa Indonesia mempunyai keunikan-keunikannya sendiri, beberapa agenda kebudayaan dapat diutarakan secara garis besar, agar bangsa Indonesia dapat tumbuh menjadi semakin kuat dan sekaligus semakin bersatu.

Di bidang poilitik, agenda kebudayaan yang perlu dilancarkan ialah mengusahakan agar pada Bangsa Indonesia tumbuh masyarakat kewargaan (civil society) yang kuat. Yang dimaksud di sini adalah suatu masyarakat dimana kelompok-kelompok sosial politik di dalamnya benar-benar saling memandang sebagai saudara sebangsa. Ini adalah agenda tertinggi dan tersulit yang harus dilaksanakan. la menjadi agenda tertinggi tertinggi sebab tanpa itu kebijakan apapun yang disusun dan disepakati di atas kertas akan selalu digerogoti oleh fragmentasi akut di dalam tubuh masyarakat bangsa kita yang tidak kohesif. la menjadi agenda tersulit sebab pada'kenyataannya bangsa Indonesia lahir dari warisan kolonial di mana berbagai komunitas sengaja dipecah-pecah secara politis patologis.
(Mochtar Pabottinggi, 1997: 67-68).

Agenda politik ini menghendaki berlakunya praktek-praktek sosial yang inklusivistik, di mana tidak ada kelompok masyarakat yang hendak memaksakan kèbenaran dan atau mempertahankan superioritasnya sendiri atas kelompok lainnya. Dalam hal ini kta tidak perlu menanti berlakunya sistem nilai inkJusivistik. Yang harus dilaricarkan adalah suatu usaha yang lebih modest dan icremental di mana satu dua orang secara berani memulaj praktek-praktek sosial demikian.

Salah satu kesalahan besar yang selama ini 'dilakukan dalam usahà membina kebudayaan ialah mengimpikàn terjadinya transformasi kuitural yang mengandaikan keserempakan. Ini sama saja dengan memimpikan kemustahilan. Pada impian itu dilupakan bahwa sistem nilai bermula dari praktek satu dua orang yang berangsurangsur menjalar pada kelompok dan komunitas. Nilai-nilai yang luhur dan dinamis tidak pernah langsung tumbuh dari orang banyak, melainkan selalu dari individu-individu yang berani dan memiliki visi. Bangsa Indonesia sangat memerlukan individu-individu demikian dan Bangsa Indonesia harus optimis bahwa individu-individu demikain selalu.ada di tengah-tengah masyarakat.

: Dalam perspektif moral, Indonesia kini dan yang akan datang diperlukan adanya pembaharuan moral. Pembaharuan moral seluruh , kehidupan, masyarakat hanya mempunyai peluang apabila didukung oleh semua kekuatan moral dalam masyarakat. Yang diperlukan tidak kurang dari sebuah koalisi ketekadan moral yang bersatu dalam tekad untuk tidak membiarkan lagi korupsi moral publik merajalela; untuk mendukung terwujudnya kehidupan berbangsa dan bernegara'yang tidak lagi meremehkan ketidakadilan, yang tidak memalukan lagi.

Koalisi itu mestinya mencakup tokohtokoh dari semua agama, kaum intelektual, sipil, militer, para pokitisi, masyarakat. Se- 
mua yang muak dengan korupsi moral sekarang, semua yang berhasrat membangun kehidupan bersama yang adil, sejahtera, beradab, dan non-diskriminatif, di mana semua golongan sama-sama dapat hidup sebagai manusia dan warga negara yang bebas dan sejahtera sesuai dengan cita-cita kemanusiaan mereka.

\section{Penutup}

Perjalanan sejarah Bangsa Indonesia telah memberikan pelajaran bagi kita semua atas kesalahan-kesalahan masa lalu terutama pada Rezim Orde Baru yang monopolistis, kolutif, nepotis represif sentralistis dan eksklusif. Tekad dan semangat reformasi merupakan wahana untuk mengkoreksi kesalahan-kesalahan yang telah dilakukan. Wacana reformasi dalam perspektif dekonstruksi mengandaikan perubahan menuju struktur atau paradigma baru yang lebih sesuai dengan tuntutan internal reformasi serta kondisi eksternal arus globalisasi.

Ini berarti, bangsa Indoensia harus dengan segala komponennya menyatukan segala kekuatan bangsa tanpa menafikkan keberagaman yang ada. Dengan demikian perubahan yang harus dilakukan atau wacana dekontruksi tidak saja berdimensi struktural melainkan yang lebih penting lagi adalah dimensi moral sebagai landasan langkah menuju Indonesia yang modem dan demokratis.

\section{DAFTAR PUSTAKA}

Alam, Rudy Harisyah, 1994, "Perspektif Pascamodernisme dalam Kajian Keagamaan", Ulumul Qur'an: Jurnal limu dan Kebudayaan, No. 1 Vol. V, 1994.

Amir Piliang, Yasraf, "Dekonstruksi Kultural Orde Baru dan Masa Depan Bangsa",
Kompas, 10 September 1998.

Assyaukanie, Luthfi 1994, "Islam dalam Konteks Pemikiran Pascamodemisme Pendekatan Menuju Kritik Akal Islam", Ulumul Qur'an: Jurnal Ilmu Kebudayaan, No. 1 Vol. V, 1994.

Denny, JA, 1993, "Merem Postmodernisme", Kompas, 3 Desember 1993.

Heryanto, Ariel, 1994, "Pascamodernisme: Mengapa Sulit Tapi Perlu", Kompas, 4 September 1993.

Hikam, Muhammad A.S, 1996, "Bahasa dan Politik: Penghampiran 'Discursive Practice $^{\text {"n }}$ dalam Yudi Latif \& Idi Subandy Ibrahim (ed), Bahasa dan Kekuasaan: Politik Wacana di Panggung Orde Baru, Mizan, Jakarta.

Langenberg, Michael van, 1996, "Negara Orde Baru: Bahasa, ldeologi, Hegemoni", dalam Yudi Latif \& Idi Subandy Ibrahim (ed), Bahasa dan Kekuasaan: Politik Wacana di Panggung Orde Baru, Mizan, Jakarta.

Mahfud MD, Moh, 1998, "Budaya Hukum dalam Konteks Reformasi", dalam Makalah Internship Dosen-dosen Ilmu Budaya Dasar se-Indonesia, Yogyakarta 18 - 27 Agustus 1998.

Noris Christopher, 1982, Deconstruction: Theory and Practice, Methuen, London.

Pabottinggi, Mochtar, 1997, "Kebudayaan dan Otosentrisitas", Ulumul Qur'an: Jumal IImu Dan Kebudayaan, NO. 4. VII/1997.

Sahal, Ahmad, 1994 "Kemudian, di Manakah Emansipasi", Kalam: Jurnal Kebudayaan, Edisi 1-1994.

Sugiharto, Bambang I, 1996, Postmodernisme: Tantangan Bagi Filsafat, Kani: sius, Yogyakarta.

Suseno, Franz Magnis, 1998, "Belajar dari Krisis", Basis: Majalah Kebudayaan Umum, No. 03-04, Tahun ke 47 MaretApril 1998. 
Topik: Reformasi Kultural Orde Baru...., Arinto Nurcahyono

Verhar, Jo, 1998, "Purnamodernisme (I):

Membuang Kemodernan", Basis:

Majalah Kebudayaan Umum, No. 0506 Tahun ke 46 Mei-Juni 1998.

םם 